International Journal of Social Science And Human Research

ISSN(print): 2644-0679, ISSN(online): 2644-0695

Volume 04 Issue 12 December 2021

DOI: $10.47191 / \mathrm{ijsshr} / \mathrm{v} 4-\mathrm{i} 12-21$, Impact factor-5.586

Page No: $3610-3620$

\title{
The Economic and Socio-Cultural Factors Affecting Performance of Women Entrepreneurs in Bangladesh: An Exploratory Study on Cumilla City
}

\author{
Fatema Akter Jeni ${ }^{1}$, Shaily Das ${ }^{2}$, Kazi Afruja Nargis ${ }^{3}$ \\ ${ }^{1,3}$ Department of Business Administration, Noakhali Science and Technology University, Noakhali-3814, Noakhali, Bangladesh \\ ${ }^{2}$ Department of Accounting \& Information Systems, Cumilla University, Cumilla, Bangladesh
}

\begin{abstract}
This study was designed to assess the economic and socio-cultural factors that affect the performance of women entrepreneurs of Cumilla city as well as Bangladesh. It also addressed the characteristics of women entrepreneurs and the supports they acquire from the surroundings. A sample of 60 women entrepreneurs engaged in different sectors was taken for the study using stratified and simple random sampling. In the process of answering the basic questions, a questionnaire that include demographic profiles, characteristics of women entrepreneurs and their enterprises, factors that affect the performance of women entrepreneurs was designed in both open and closed ended questions. After the data has been collected, it was analyzed using simple statistical techniques (tables and percentages) and descriptive statistics (mean and standard deviations) and F-Test Two-Sample for Variances. In F-Test Two-Sample for Variances, $\mathrm{P}$ value is 0.035433248 ; which is less than $0.05(\mathrm{P}<0.05)$; which means that there is difference between variance of two factors in women entrepreneurship. The difference between the two variances is statistically significant. This condition indicates that the sample provides strong enough evidence to conclude that the variability in the two factors is different. F-Test Two-Sample for Variances analysis reveals that there is significant impact of economic and socio-cultural factors on women entrepreneurship The results of the study indicates the personal characteristics of women entrepreneurs which affect their performance .It also shows that lack of financial access, stiff competition, inadequate access to training, access to technology and access to raw materials are the key economic factors that affect the performance of women entrepreneurs. Based on the major findings, recommendations were suggested to existing and potential entrepreneurs, Micro finances and other institutions. Both the government organizations and private sector have a major responsibility to promote entrepreneurship development for women. Without their interventions the advancement of women and women entrepreneurship cannot be achieved.
\end{abstract}

KEY WORDS: Entrepreneurs, Women Entrepreneurship, Performance, Influential factors Problems, Prospects, Bangladesh.

\section{INTRODUCTION}

Economic empowerment of women is considered as an indispensable part of development discussions. Women entrepreneurs symbolize a large number of women who discover new prospects of economic participation. Bangladesh is a developing country which positioned in South Asian region and is a populated country where about 50\% of the population falls below income poverty line. Women constitute about half of the population of Bangladesh. The participation of women is not as noticeable as the participation of men. The power of the majority of the female population should point to the necessity of using their full potential for economic growth and development. In this connection, Chowdhury (2001) Deliberates that in current years developing countries around the world, including Bangladesh, have concentrated on raising consciousness about the most disadvantaged group in society - women. Those concerned are slowly realizing that discrimination on a gender issue cannot waste nearly half of its human resources. This growing awareness on the part of the government has led to the implementation of national policies so that a development process involving women in all fields focuses on economic activities, especially entrepreneurial development. Entrepreneurship has become an important profession among the women of Bangladesh at different levels of society. The reasoning behind this interest varies according to different classes of society [1].

Entrepreneurship is considered to be one of the most important determinants of industrial growth in both developed and developing countries. Women entrepreneurs have become important performers in the entrepreneurial background. According to the UNDP: Human Development Report (2004), A female entrepreneur is a woman who has started or inherited a business alone or with one or more partners, and is interested in taking financial, administrative and social risks and responsibilities and participating in day- 


\section{The Economic and Socio-Cultural Factors Affecting Performance of Women Entrepreneurs in Bangladesh: An Exploratory Study on Cumilla City}

to-day activities [2]. Braun (2011) explained that women entrepreneurs have improved their living conditions and gained more respect in the family and the society [3].

Women have been increasing interest in income generating activities, self-employment and entrepreneurship in recent years. It is seen in respect of both types of women in both urban and rural areas. Women are taking up both traditional activities (knitting, pickle making, toy making, jam and jelly) and also nontraditional activities (computer training, catering services, beauty parlor, gym etc.). It is clear that more and more women are coming forward to set up enterprises. In the entrepreneurial process, women have to face various problems related to entrepreneurship and these problems are doubled because she had a dual role as a wage earner and a domestic worker.

The main objective of the study is to find out of the assessment of the economic and socio-cultural factors that affects the performances of women entrepreneurs in Cumilla city.

The specific objectives of the study are:-

- To have an overview of present state of women entrepreneurship in Cumilla city.

- To propose some recommendations to remove the obstacles by utilizing the opportunities for the growth and development of women entrepreneurship in Cumilla city.

The study will convey the messages about the factors which affect the performances of women entrepreneurs of Cumilla city as well as Bangladesh in running their own businesses and recommend the appropriate measures to be taken like if women are provided with appropriate training and financial assistance; they will enter into the entrepreneurial occupation in a large number and will prove their worth to contribute to the economy of Bangladesh. This study makes attempt to high-light the activities of women entrepreneurship in the urban areas of Cumilla city. The study also discusses the entrepreneurial qualities of women in Cumilla city and their socio-economic status to understand whether these facilitate or constrain women to emerge as successful entrepreneurs. Keeping the objectives in mind, questions were asked to extract information from randomly selected entrepreneurs. Data will be collected through field work have been carefully processed, analyzed and presented in the form of table with statistical interpretation.

\section{LITERATURE REVIEW}

Entrepreneurship is a dynamic process of creating increased wealth. Individuals create wealth that yields risks in terms of equity, time and / or carrier liability to compensate for certain products or services. Although the product or service may or may not be new, the businessperson must provide worth by obtaining and distributing the necessary assistances and resources.

Begum (1993) identifies that an entrepreneur can be defined as one who initiates and establishes an economic activity or enterprise. Entrepreneurship thus refers to the general trend of setting up new enterprises in a society. [4]

It is identified that an entrepreneur can be described as one who recruits and launches a financial activity or venture and Entrepreneur thus refers to the general tendency to set up new ventures in a society.

Khanka (2002) states women entrepreneur are the person who invent, emulate, or take on endeavor. Entrepreneurship is a group of activities accomplished by an entrepreneur; it may be argued that before becoming an entrepreneur. [5]

John (2004) conferred that distinguishing entrepreneurs is essential in order to upheld female entrepreneurship. [6]

Rinkal et al., (2004) suggested that women today differ in many ways from women of previous years. At the present time, they pursue social and economic freedom and are willing to take risks for it. [7]

Mitchell (2004) observed that, now-a-days women entrepreneurs are influenced by the demand of providing protection to their families and for their families' circumstances. As the basic necessity of women entrepreneur is to be financially independent, for this reason they need to be motivated and otherwise. Entrepreneurship permits women to take care of their families while earning the money needed for daily survival. This movement has also been seen in several Asian countries, including Indonesia and Singapore. [8]

Watson (2003) states that there are a moderate number of probable systemic changes between male and female owners that could explain why women-owned businesses operate inferior to male-owned businesses. Women-owned business age, family commitment, low access to capital, different levels of education, previous business experience and attitude towards risk are significant factors. [9]

Garga and Baga (2009) states that those women as a single or group who start, establish and manage a business venture. [10]

Jesselyn (2004) observed that, the qualities of women entrepreneurs should be exploited in the developing countries. When a person is capable of transform his concepts into accomplishment and also include imagination, entrepreneurial feeling, invention and risk taking, along with the aptitude to design and accomplish projects to attain goals. [11]

Gemechis, (2007) observed that women create their own enterprises and become entrepreneurs as the chances of getting of a job is becoming difficult in either a private organization or government; non-government organization and the number of the organization are declining. [12] 


\section{The Economic and Socio-Cultural Factors Affecting Performance of Women Entrepreneurs in Bangladesh: An Exploratory Study on Cumilla City}

Jahed et al., (2011) states that the economic empowerment of women is an essential part of the discussion of modern development in any development initiative of a nation. The empowerment of women depends on their participation in various development activities. Studies have shown that women involved in entrepreneurial activities have empowered them socially, economically and culturally. Despite recent advances in Bangladesh's progress and empowerment, women are vulnerable to poverty and social deprivation. [13]

Shane \& Venkataraman, (2000) states that recognition of opportunities is one of the reasons for influencing the performance of women entrepreneurs. Although entrepreneurial opportunity identification is a subject matter, opportunity itself is a purposeful phenomenon that is recognized by particular individuals at a particular time. [14]

De Carolis and Saparito, (2006); Phyllis, (2009). Observed that researchers have highlighted entrepreneurship in stimulating new venture expansion and also in identifying and achieving new entrepreneurial. [15]

Anderson \& Miller, (2002) identifies that the effectiveness of a business venture will depend on how an entrepreneur recognizes opportunities and determines which opportunities to pursue. [16]

\section{RESEARCH METHODOLOGY}

Simply, a random sample is a subset of randomly selected individuals by researchers to represent an entire group. The goal is to get samples from representatives of the larger population. Random sampling procedure is followed to select the sample. Number of total sample is 60. Samples have been taken from Cumilla city. The required data has been collected from women entrepreneurs of Cumilla region in Bangladesh. The specific study area has been selected on the basis of availability of women entrepreneurs. A set of questionnaire prepared to conduct the field survey. The questionnaire included only close-ended questions. For conducting the research both primary and secondary data has been used from different sources. The primary data has been collected at the field level through questionnaire, survey and interview. Data has been collected with the help of structured questionnaire. To extract data through field-work, a written questionnaire was designed. The questionnaire was both an open-ended and closed-ended. Secondary Sources of information/data has been collected from published materials such as annual reports of different Organizations, books, Journals, Magazines, Newspapers etc. To process and analysis the data, a combination of research techniques used to provide the most comprehensive research results. The data has been collected through the above methods i.e. both from the primary and secondary sources have been carefully processed and presented in the form of table, graph and analyzed with the help of different tools by using MS Excel, descriptive statistics and F-Test Two-Sample for Variances.

\section{DEMOGRAPHIC INFORMATION}

\subsection{Data presentation and Analysis:}

Data is presented in the form of tables collected from the women entrepreneurs of the Cumilla region. Keeping in view of the objectives of the study, relevant questions were asked to extract information from them.

\section{Table 1.Women entrepreneurs by Education Level}

\begin{tabular}{|l|l|l|}
\hline Education & Number & Percentage \\
\hline SSC & 8 & $13 \%$ \\
\hline HSC & 14 & $23 \%$ \\
\hline HONOURS & 24 & $40 \%$ \\
\hline MASTER & 14 & $24 \%$ \\
\hline Total & 60 & $100 \%$ \\
\hline
\end{tabular}

Source: Field survey

It should be mentioned that education, entrepreneurship and development are interrelated. Education is known to be the best means of developing a person's capabilities that encompass different dimensions of entrepreneurship. Formal education is always important for a career. Educated persons can acquire easily skills necessary for development of entrepreneurship. Table-1 shows that out of 60 respondents, 24\% has Master's degree, 40\% has Honours degree, 23\% have HSC and 13\% has SSC. So, it can be said that most of the respondents are well educated which have a great impact on their performances in their respected business.

\subsection{Types of enterprises owned}

Table 2.Entrepreneurship pattern

\begin{tabular}{|l|l|l|}
\hline Types of Business & Number & Percentage \\
\hline Boutique House & 24 & $40 \%$ \\
\hline Restaurant & 20 & $33 \%$ \\
\hline Parlour & 16 & $27 \%$ \\
\hline
\end{tabular}

Source: Field survey 
The Economic and Socio-Cultural Factors Affecting Performance of Women Entrepreneurs in Bangladesh: An Exploratory Study on Cumilla City

Table: 2 show that among 60 respondents, $40 \%$ enterprises are boutique House, 33\% enterprises are Restaurant and 20\% have Parlor. Now, women are started to exploring new sectors as their working sites and trying to bringing the change in their business.

4.3 Confronting problems because of gender.

Table 3. Gender Discrimination

\begin{tabular}{|l|l|}
\hline Response & Percentage \\
\hline Yes & $65 \%$ \\
\hline No & $35 \%$ \\
\hline
\end{tabular}

Source: Field-work

Table-3 shows that Most of the countries women are facing gender discrimination especially in outdoor work. In cumilla city $65 \%$ respondent ensure that they are facing many problem because of they are women.so it's quite negative sign in terms of improvement in this sector because it hinders the performances of women entrepreneurs badly. So, it's kind of a great negative factor that affects the performances of women entrepreneurs. On the other hand, 35\% respondents said that they are not facing any gender discrimination in terms of working in their field.

\subsection{Source of capital to start business}

Table 4. Capital pattern

\begin{tabular}{|l|l|}
\hline Source of Capital & Percentage \\
\hline Own Savings & $53 \%$ \\
\hline NGO & $10 \%$ \\
\hline Bank Loan & $17 \%$ \\
\hline Relatives & $20 \%$ \\
\hline \multicolumn{2}{|l|}{ Source: Field survey } \\
\end{tabular}

Table 4 shows that among the 30 respondents, $53.33 \%$ women entrepreneurs invested money from the own source, $10 \%$ from NGO's, $16.67 \%$ took bank loan and $20 \%$ invested money from relatives. As the maximum respondent started business with their own savings so it can be said that they can run their business without any accountability to others which have a positive impact on their performances. On the other hand it seems that as sometimes own savings isn't enough for carrying out a business, they need more fund but lacking of credit access is the most negative factors for running a business. So, it creates a negative impact on their performances.

\subsection{Pattern of Business}

Table 5. Ownership Pattern

\begin{tabular}{|l|l|}
\hline Ownership Pattern & Percentage \\
\hline Sole & $77 \%$ \\
\hline Partnership & $23 \%$ \\
\hline
\end{tabular}

Source: Field survey

Table- 5 shows that out of 60 respondents, $77 \%$ women entrepreneurs have sole business and $23 \%$ women entrepreneurs have partnership business. As $77 \%$ women have sole business in which women can take all their decision easily and run their business on their own way so, it seems to have a huge impact on entrepreneurs. Taking decisions easily is a positive factor for every entrepreneur and it creates a vast impact on their performances.

\subsection{Basis of doing Business}

Table 6.Basis of Business in Percentage

\begin{tabular}{|l|l|}
\hline Basis of Business & Percentage \\
\hline Online & $57 \%$ \\
\hline Offline & $43 \%$ \\
\hline
\end{tabular}

Source: Field-work

Table -6 shows that among 60 respondents $57 \%$ operate their businesses in online or home delivery basis which is feasible for the customers. By this process women can easily establish their business by their own self without much effort and it makes them more 
The Economic and Socio-Cultural Factors Affecting Performance of Women Entrepreneurs in Bangladesh: An Exploratory Study on Cumilla City

comfortable to do their business which seems to a factor that affects their performance. On the other hand $43 \%$ respondents doing their business in offline basis. They have different working place i.e., showroom, restaurant.

4.7. Training before starting the business

Table 7. Response for training

\begin{tabular}{|l|l|}
\hline Response for training & Percentage \\
\hline Yes & $73 \%$ \\
\hline No & $27 \%$ \\
\hline
\end{tabular}

Source: Field-work

Table-7 shows that Training before starting the business is an important matter to understand entrepreneurship. Among the 60 women respondents, only $27 \%$ takes training on their owns and $73 \%$ have no training experience which is very crucial for them. So, it creates a negative impact on the performances of women entrepreneurs. Women entrepreneurs face the problem of increasing their experiences skills because of underprivileged and inadequate training facilities in all over the country.

4.8. Age of Business

Table 8. Age of business in percentage

\begin{tabular}{|l|l|l|}
\hline Age & No & Percentage \\
\hline 0-2 years & 28 & $47 \%$ \\
\hline 3-6 years & 20 & $33 \%$ \\
\hline 7-10 years & 8 & $13 \%$ \\
\hline 11-more & 4 & $7 \%$ \\
\hline Total & 60 & $100 \%$ \\
\hline
\end{tabular}

Source: Field-work

Among 60 respondents the age of $47 \%$ women's business is below 2 years, $33 \%$ women's business is $3-6$ years, $13 \%$ women's business is 7-10 years and 7\% women's business is 11 years or above. The above table shows that maximum women entrepreneurs are less experienced which create lots of confusions, dilemma in their business sectors and which have some negative impact on their respected business cause this condition hinders their performance as well as their confidence level. So, it's a factor of thought for all entrepreneurs.

\subsection{Reason for being an entrepreneur}

Table 9. Reason for being an entrepreneur in percentage

\begin{tabular}{|l|l|}
\hline Reasons for being an entrepreneur & Percentage \\
\hline Financial need & $40 \%$ \\
\hline Hobby & $27 \%$ \\
\hline Father/ Hobby Business & $23 \%$ \\
\hline Creating Employment & $10 \%$ \\
\hline Source: Field-work
\end{tabular}

Table- 9 shows that out of 60 respondents $27 \%$ doing their business because of hobby, $40 \%$ doing their business because of financial need, $23 \%$ doing their business because of continuing their father or spouse business and 10\% doing their business for creating employment.

As maximum respondent running their business because of financial needs so they might be so much sincere and industrious to their work. Their needs peddle them to work diligently and it seems that the reason behind doing the business is a positive factor which has a great impact on the performance of women entrepreneurs.

4. 10. Amount of initial capital for starting the business

Table 10. Amount of initial capital

\begin{tabular}{|c|l|}
\hline Investment for business & Percentage \\
\hline Below 20000 & $33 \%$ \\
\hline $20000-50000$ & $23 \%$ \\
\hline $50000-100000$ & $27 \%$ \\
\hline $100000-200000$ & $17 \%$ \\
\hline
\end{tabular}

Source: Field survey 


\section{The Economic and Socio-Cultural Factors Affecting Performance of Women Entrepreneurs in Bangladesh: An Exploratory Study on Cumilla City}

Among the 60 respondents, 33\% women entrepreneurs invested less than 20,000,23\% women invested 20000-50000, 27\% women invested 50000-100000 and 17\% had invested more than TK.100,000/-.

\section{Factors Affecting Performances of Women Entrepreneurs in BANGLADESH}

According to Roy et al., (2017). Entrepreneurs are usually considered as sort of pioneering, empathetic and risky people. Moreover, for the purpose of economic development, women entrepreneurs are considered as imperative. Not only have they contributed to job creation and economic growth through their growing numbers, but they have also contributed to the variation of entrepreneurs in the cost-effective process [17]. Hasan and Al-Mubarak, (201) identifies that, Women entrepreneurs should know different features of starting a business, the motivation level to do so and their performance level in the venture [18]. More than half of the population in Bangladesh is women but it is a matter of regret that the percentage of their active involvement in the financial system is moderately low. The country should motivate women for becoming entrepreneurs and as a result, it will bring financial affluence and also progress the excellence of life. So, entrepreneurship is considered a vital factor for financial betterment of any country.

Over the past decade, the number of women entrepreneurs around the world has grown exponentially, and the prospect for women entrepreneurship has progressively changed the rustic economy in several parts of the world. But the problems cannot be entirely solved with this drastically changes.

Three distinct factors influences entrepreneurship: economic factor, socio-cultural factor and The emergence of entrepreneurship may have been affected by these factors in both positive and negative way. Positive effects create favorable and favorable conditions for the emergence of entrepreneurs, where negative effects hinder the emergence of entrepreneurs.

\section{ECONOMIC FACTORS}

The economic environment has the most direct and immediate impact on entrepreneurs. This is probably because people become entrepreneurs because they have no other job or because of opportunity or need.

Samit (2006) states that among the major economic factors that affect the performance of women entrepreneurs Finance, markets, training, land, information, management skills, infrastructure and raw Materials. [19]

Three distinct factors influences entrepreneurship: economic factor, socio-cultural factor and legal and administrative factor. The emergence of entrepreneurship may have been affected by these factors in both positive and negative way. Positive effects create favorable and favorable conditions for the emergence of entrepreneurs, where negative effects hinder the emergence of entrepreneurs.

Table 11. Economic factors that affect the performance of women entrepreneurs

\begin{tabular}{|c|c|c|c|c|c|c|c|c|c|c|}
\hline SL No. & Economic Factors & Mean & $\begin{array}{l}\text { Standard } \\
\text { Deviation }\end{array}$ & $\begin{array}{l}\text { Sample } \\
\text { Variance }\end{array}$ & Kurtosis & Skewness & Min & Max & $\begin{array}{l}\text { Confidence } \\
\text { Level } \\
(\mathbf{9 5 . 0 \% )}\end{array}$ & $\begin{array}{l}\text { Rank of } \\
\text { Severity }\end{array}$ \\
\hline 1. & $\begin{array}{l}\text { Satisfaction with the getting of } \\
\text { trade license }\end{array}$ & 2.271 & 0.827 & 0.683 & -0.419 & 0.207 & 1 & 4 & 0.215 & 6th \\
\hline 2. & $\begin{array}{l}\text { Better access to information to } \\
\text { exploit business opportunities. }\end{array}$ & 3.016 & 0.754 & 0.569 & -1.211 & -0.028 & 2 & 4 & 0.197 & 10th \\
\hline 3. & Moderate market competition & 2.796 & 0.737 & 0.544 & -1.070 & 0.345 & 2 & 4 & 0.192 & 9th \\
\hline 4. & $\begin{array}{l}\text { Better access to different } \\
\text { business } \\
\text { training }\end{array}$ & 1.847 & 0.761 & 0.579 & -0.319 & 0.509 & 1 & 4 & 0.198 & 4th \\
\hline 5. & Surplus marketing skill & 1.949 & 0.818 & 0.699 & -0.372 & 0.486 & 1 & 4 & 0.213 & 5th \\
\hline 6. & Availability of capital & 1.440 & 0.749 & 0.561 & -1.758 & -1.610 & 1 & 4 & 0.195 & 2nd \\
\hline 7. & $\begin{array}{lll}\begin{array}{l}\text { Adequate } \\
\text { experience }\end{array} & \text { amount } & \text { of } \\
& & \end{array}$ & 1.728 & 0.784 & 0.614 & 0.700 & 0.969 & 1 & 4 & 0.204 & $3 \mathrm{rd}$ \\
\hline 8. & Availability of raw materials & 2.745 & 0.862 & 0.744 & -0.853 & 0.025 & 1 & 4 & 0.224 & 8 th \\
\hline 9. & Adequate infrastructure & 2.593 & 0.892 & 0.797 & -0.720 & 0.009 & 1 & 4 & 0.232 & 7 th \\
\hline 10. & Adequate amount of own land & 1.271 & 0.485 & 0.235 & -1.360 & -1.515 & 1 & 3 & 0.126 & 1 st \\
\hline \multicolumn{2}{|c|}{ Grand mean/ Standard deviation } & 2.17 & 0.11 & & & & & & & \\
\hline
\end{tabular}

$[$ Here, Min. $=$ Minimum and Max. $=$ Maximum $]$ 


\section{The Economic and Socio-Cultural Factors Affecting Performance of Women Entrepreneurs in Bangladesh: An Exploratory Study on Cumilla City}

1. It is discussed that in the table 11 above the mean score (1.271) and the standard deviation score (0.485) for the availability amount of own land. In the table, it is seen that, rank of severity of this factor is first. It means that, the respondent's women entrepreneurs in the Cumilla city don't have own land. So, they cannot maintain their business in an easy way. They have to run their business by renting a shop, which has an impact in their business in a negative way.

2. Another economic factor, the availability of capital has very average mean score (1.440) and standard deviation (0.479), which stood in the $2^{\text {nd }}$ position in the rank of severity. It means that, the women entrepreneurs of the Cumilla city are not satisfied with different sources of capital. They cannot get fund to run their business from different financial institutions such as bank loan, SME loan, NGOs, non- banking financial companies etc. Initially, most of the women entrepreneurs manage their capital from their own savings and also from their families.

3. Women entrepreneurs who are respondents of this article don't have enough experience in their business sector which is seen by the mean score (1.728) and by the standard deviation $(0.784)$, which stood in the $3^{\text {rd }}$ position in the rank of severity.

4. Women entrepreneurs in Comiila city now-a-days get moderate level of training. Which is justified by the mean score (1.847) and standard deviation (0.761). Training is provided by different govt. and non-govt. organizations in sewing, dress sewing, food and confectionary etc.

The access for different business trainings for the women respondents is low. This factor rank of severity is forth.

5. Women entrepreneurs have moderate level of managerial skill which is seen by the mean score (1.949) and standard deviation (0.818). As they operate their business by themselves and rarely by their personnel, managerial skill slowly grows in them. This factor rank of severity is fifth.

6. Women entrepreneurs in Comilla city are moderate level of satisfied with in getting their trade license as their mean score (2.271) and the standard deviation score (0.827). They have been face problems in getting their trade license. Most of the respondents didn't have enough knowledge about registration. They are also facing financial problems and some of the respondents didn't feel the need of having trade license. They also added that as their business is new, they would apply for the license when their business extended. This factor rank of severity is sixth.

7. Another economic factor, adequate infrastructure has medium level mean score (2.593) and standard deviation (0.892). This means that women entrepreneurs as respondents express their satisfaction level with adequacy of infrastructure. They rent a show room and then furnish them. Most of the respondents agree on the availability of the necessary infrastructures around their working areas. This factor rank of severity is seventh.

8. Women entrepreneurs in Comilla city are expressing their satisfaction with the availability of raw materials with the mean score (2.745) and standard deviation (0.862). They can collect the raw materials of their business from their near market. In restaurant business, they can buy vegetables, fish, meat, spices etc. from their new market and in parlor business, makeup kid, different machine etc. and in also boutique business, sewing machine, cloth, sewing thread etc. This factor rank of severity is eighth.

9. With regard to market competition, the mean scores (2.796) and standard deviation (0.737) shows that respondents agree with an idea that there is no stiff competition in the market among the competitor. Because, women are engaging in business from some years before. So this business did not spread well. This factor rank of severity is ninth.

10. However, these women entrepreneurs respond that they have a better access to information to exploit different business opportunities. As the mean score (3.016) and standard deviation (0.754) clearly depicts, the respondent entrepreneurs agree on their better access to information.

This factor rank of severity is tenth.

\section{SOCIO- CULTURAL FACTORS}

Socio-cultural issues include a mix of social and cultural issues that affect the success of women entrepreneurs. Therefore, Rumi et al. (2018) suggest that women's entrepreneurial career choices both revolve around and are formed by a complex interaction of socio-cultural factors [20]. According to Veciana, ( 1999). Socio-cultural factors determine the level of entrepreneurial activity at a particular time and place [21]. Although Arasti, Jandi, and Talebi (2012) explained that social relationships have a significant impact on women's business performance and success. It gives business dreamers the ability to better differentiate between opportunities and resources [22]. 
The Economic and Socio-Cultural Factors Affecting Performance of Women Entrepreneurs in Bangladesh: An Exploratory Study on Cumilla City

Table 12. Socio-cultural factors that affect the performance of women entrepreneurs

\begin{tabular}{|c|c|c|c|c|c|c|c|c|c|c|}
\hline $\begin{array}{l}\text { SL } \\
\text { No. }\end{array}$ & $\begin{array}{l}\text { Socio-cultural } \\
\text { Factors }\end{array}$ & Mean & $\begin{array}{l}\text { Standard } \\
\text { Deviation }\end{array}$ & $\begin{array}{l}\text { Sample } \\
\text { Variance }\end{array}$ & Kurtosis & Skewness & Min & Max & $\begin{array}{l}\text { Confidence } \\
\text { Level }(95.0 \%)\end{array}$ & Rank of Severity \\
\hline 1. & $\begin{array}{ll}\text { Better } & \text { social } \\
\text { acceptability } & \end{array}$ & 3.118 & 0.744 & 0.544 & -1.145 & -0.196 & 2 & 4 & 0.194 & 6th \\
\hline 2. & $\begin{array}{l}\text { Good } \\
\text { Communication } \\
\text { (network) with the } \\
\text { outsiders }\end{array}$ & 3.610 & 1.000 & 1.000 & -0.973 & -0.207 & 2 & 5 & 0.260 & 7 th \\
\hline 3. & $\begin{array}{lr}\text { Facing } & \text { no } \\
\text { discrimination } & \text { or } \\
\text { class conflict } & \end{array}$ & 1.728 & 0.805 & 0.649 & -0.407 & 0.744 & 1 & 4 & 0.209 & 2nd \\
\hline 4. & $\begin{array}{ll}\text { Increased } & \text { self- } \\
\text { confidence } & \end{array}$ & 4.186 & 0.753 & 0.568 & -1.154 & -0.325 & 3 & 5 & 0.196 & 8 th \\
\hline 5. & $\begin{array}{l}\text { Improve relationship } \\
\text { with others }\end{array}$ & 4.355 & 0.482 & 0.233 & -1.676 & 0.617 & 4 & 5 & 0.125 & 9th \\
\hline 6. & $\begin{array}{lr}\text { Facing } & \text { no } \\
\text { conflicting } & \text { gender } \\
\text { bias } & \end{array}$ & 1.389 & 0.276 & 0.276 & -0.537 & 0.829 & 1 & 3 & 0.137 & $1 \mathrm{st}$ \\
\hline 7. & $\begin{array}{l}\text { Societies attitude } \\
\text { towards business is } \\
\text { positive }\end{array}$ & 2.898 & 0.844 & 0.713 & -1.036 & 0.375 & 2 & 5 & 0.220 & 5 th \\
\hline 8. & $\begin{array}{lr}\text { Facing } & \text { no } \\
\text { difficulties } & \text { in } \\
\text { registering } & \text { and } \\
\text { operating business }\end{array}$ & 2.118 & 0.948 & 0.899 & -0.801 & 0.383 & 1 & 4 & 0.247 & 3rd \\
\hline 9. & $\begin{array}{l}\text { Having strong } \\
\text { financial position }\end{array}$ & 2.457 & 1.119 & 1.252 & -1.347 & 0.071 & 1 & 4 & 0.291 & 4th \\
\hline \multirow[t]{2}{*}{10.} & $\begin{array}{ll}\text { Increased } & \text { social } \\
\text { status } & \end{array}$ & 4.732 & 0.076 & 0.584 & -0.679 & -0.286 & 3 & 5 & 0.152 & 10th \\
\hline & $\begin{array}{l}\text { Grand mean/ } \\
\text { Standard deviation }\end{array}$ & 3.06 & 0.31 & & & & & & & \\
\hline
\end{tabular}

$[$ Here , Min. $=$ Minimum and Max. $=$ Maximum $]$

1. Women entrepreneurs in Comiila city are faces huge conflicting gender bias for running their business which is justified by the mean (1.389) and standard deviation (0.276). Most of the female entrepreneurs don't get enough inspiration from their near and dear ones to start their business. They become the victim of gender discrimination. The rank of severity of tis factor is $1^{\text {st }}$.

2. Women entrepreneurs' faces discrimination or class conflict in Comilla city which is justified by the mean (1.728) and standard deviation (0.805). Women, who are from middle class or lower class families, deprived of different benefits such as getting trade license, learning of technical know-how about business etc. The rank of severity of tis factor is $2^{\text {nd.. }}$

3. The mean scores (2.118) and standard deviation (0.948) of the respondents in table 12 shows that women are facing massive difficulties in registering and operating business. Most of the women entrepreneurs are not aware of license, tax and VAT. Most of them lack capacity to maintain accounts, bookkeeping and other necessary documents. The rank of severity of tis factor is $3^{\text {rd }}$.

4. Women entrepreneurs don't bear strong financial position in Comilla city which is seen by this mean (2.457) and standard deviation (1.119). As they are novice in this sector, they aren't enough mature to maintain a powerful financial position. The rank of severity of tis factor is $4^{\text {th }}$.

5. Women entrepreneurs of this city agree that the society's attitude towards business is positive which is seen by the mean (2.898) and standard deviation (0.844) . Because they are doing this business in addition to their housework. They have brought financial prosperity in their family. The rank of severity of tis factor is $5^{\text {th }}$.

6. Women entrepreneurs of this city also admit that they got moderate social recognition as the society's attitude towards business is positive. The rank of severity of this factor is $6^{\text {th }}$.

7. The mean (2.898) and the standard deviation (0.844) justifies the women entrepreneurs in Comilla city has good Communication (network) with the outsiders. As they perform their business related works, they have to maintain good relationship with different parties of the business such as customer, supplier etc. The rank of severity of this factor is 7 th. 


\section{The Economic and Socio-Cultural Factors Affecting Performance of Women Entrepreneurs in Bangladesh: An Exploratory Study on Cumilla City}

8. Self-confidence is the most crucial thing for any business person. The mean (4.186) and the standard deviation ( 0.753) validates that the entrepreneurship program increases self-confidence of women entrepreneurs. From the survey it can be said that confidence, increasing social status affects the performances of women entrepreneurs. The rank of severity of this factor is $8^{\text {th }}$

9. Engaging in women entrepreneurship improves the relationship with others. The mean (4.355) and the standard deviation $(0.482)$ indicate this. The rank of severity of this factor is $9^{\text {th }}$.

10. Women entrepreneurship enhances their social status and leads to integration of women in nation building and economic development which is justified by the mean (4.732) and standard deviation (0.076). The rank of severity of this factor is $10^{\text {th }}$.

\section{Hypothesis Testing}

$\mathrm{H}_{\mathrm{o}}$ : There is no significant impact of economic and socio-cultural factors on women entrepreneurship.

$\mathrm{H}_{1}$ : There is significant impact of economic and socio-cultural factors on women entrepreneurship.

\begin{tabular}{|l|l|l|}
\hline F-Test Two-Sample for Variances & \\
\hline & Socio-cultural factors & Economic factors \\
\hline Mean & 3.0591 & 2.1656 \\
\hline Variance & 1.321113656 & 0.368532044 \\
\hline Observations & 10 & 10 \\
\hline df & 9 & 9 \\
\hline F & 3.584799953 & \\
\hline $\mathrm{P}(\mathrm{F}<=\mathrm{f})$ one-tail & 0.035433248 & \\
\hline F Critical one-tail & 3.178893104 & \\
\hline
\end{tabular}

Since, $\mathrm{P}$ value is 0.035433248 ; which is less than $0.05(\mathrm{P}<0.05)$; which means that there is difference between variance of two factors in women entrepreneurship. Socio-cultural factors have a higher variance compared with economic factors. The difference between the two variances is statistically significant. This condition indicates that the sample provides strong enough evidence to conclude that the variability in the two factors is different.

F-Test Two-Sample for Variances analysis reveals that there is significant impact of economic and socio-cultural factors on women entrepreneurship. Therefore, Null hypothesis that "there is no significant impact of economic and socio-cultural factors on women entrepreneurship" is rejected and alternative hypothesis is accepted.

From the study it has been found that the women entrepreneurs in Cumilla city faced many challenges in starting and also running up their business. Some important findings are given below:

- Among 60 respondents $20 \%$ think that high risk taking ability is the key factor of entrepreneurship; $25 \%$ think that land, labour, capital is the key factor; $35 \%$ think that innovation \& creativity is the key factor and $20 \%$ think that need for achievement is the key factor for any entrepreneurship.

- Both economic and socio-cultural factors have positive effect on women entrepreneurship. But an economic factor has a high impact on the performances of women entrepreneurs.

- The main business starting problems is lack of required funds or capital and adverse social environment which affects the performances of women entrepreneurs.

- Most Women entrepreneurs started their business by their own savings. It is a negative factor which mentioned that the government support from public and private bank at starting business was not found to be significant. It heavily affects the performance of women entrepreneurs.

- It is found from the study that when women go to the bank for loan the bank seek male support to endorse the loan. It is immense discriminatory which is not ignorable.

- Training before starting the business is an important matter to understand entrepreneurship. It is found that among the 60 women respondents, only $27 \%$ takes training in their owns and $73 \%$ have no training experience. That's why most of the women facing problem during their business work.

- Female entrepreneurs generally face problems in marketing their products. This is due to their inadequate knowledge of marketing; non-availability of marketing information; inability to estimate demand for products and services.

Despite all of these problems women are ready to do something new which creates future prospects for women entrepreneurs themselves and also the economy as a whole.

- Socio-cultural factors are positively affecting the performances of women entrepreneurs. 


\section{The Economic and Socio-Cultural Factors Affecting Performance of Women Entrepreneurs in Bangladesh: An Exploratory Study on Cumilla City}

- Study has found that women of the day want to be more independent, create their own identity as well as earn money which helps to contributes with their family income.

- It is noticeable from the study that despite of having children women are involved in the business. They maintain both family and business life successfully.

- Online system of trading helps women to do business. More than half (57\%) of the respondents operate their businesses in online or home delivery basis which is feasible for the customers. By this process women can easily establish their business by their own self without much effort.

- As women now contribute to their family income, so they get family support easily compared to the past.

- Around 57\% respondents believe that their relationship with their husband and family members improved because of their contribution.

- It is found from the study that in cumilla city around 50\% respondents attained profit from their business. So it creates a positive impact on the performance of women entrepreneurs.

\section{RECOMMENDATIONS AND CONCLUSION}

Entrepreneurship development in the country should receive top priority and integrated effort is necessary from all quarters. After analyzing the above findings we can recommend the following suggestion for the betterment of the women entrepreneurs of Comilla city as well as all over Bangladesh. These initiatives can be significant steps for improving the standard of entrepreneurs in this area.

- Government should come forward at first followed by NGOs; SMEF to meet financing need of women entrepreneurs since financing is their major problem.

- The government can offer few particular opportunities like initial funding, training and motivation for women entrepreneurs.

- Information and communication system support for all women entrepreneurs to expand and progress their business.

- Simplifying the credit system of public banks and financial institutions means that the credit systems which are being offered by different financial institutes and banks must be free from any sort of complexity and the process must be easy to realize.

- Courses should be introduced on Entrepreneurship in both formal and informal educational institutions in Bangladesh.

- Designing and maintaining the training programs for the improvement of women entrepreneurs.

- The societal attitude should be positive towards women entrepreneurs.

- Long-term financial support: there has a scarcity of long term financial support among women entrepreneurs and most financial institutes offer the short and intermediate term loans to women entrepreneurs in the area.

- Government should provide technological training to women entrepreneurs for improving their technological skill as now most of the women are doing their business in online basis.

- One should come in the business field only after a good analysis of her SWOT factors and the probability of overcoming threats and weaknesses against implementation of the opportunities and strengths.

- Co-organizing convention of women entrepreneurs, discussion meetings on the problems and prospects of women entrepreneurship in Bangladesh in the grass root level.

- Government should create more marketing opportunities

Women entrepreneurship in Bangladesh is more than just income generation. It is about working to build a more prosperous country, to lift the millions of Bangladeshi people out of poverty. It is about achieving economic independence and women's empowerment. And it is about striving for emancipation of women's gender roles, to create a better future for generations of women to come. The rights policy adjustment, their proper implementation, and other necessary initiatives will pave the way for the emergence and development of women-owned small and medium enterprise all over Bangladesh. These actions will not only contribute significantly to the national economy but will economically and socio-culturally empower women, assisting in their gender role liberalization.

The problems and prospects found out in the study based on women entrepreneurs of Cumilla area of Bangladesh will be helpful for understanding the overall scenario of women entrepreneurs of Bangladesh and there will create the opportunities to the investors and promoters as well as to Government for the purpose of planning and decision making. The study suggests every public private efforts and non-government organizations to assist the women entrepreneurs of Cumilla districts of Bangladesh because this can create larger women entrepreneur for SMEs.

\section{REFERENCES}

1) Chowdhury, Masuda M. Rashid (2001). The Emerging Women Entrepreneurs of Bangladesh, FBCCI Journal, Volume 2, Issue 5-6, September-October ,pp1 
The Economic and Socio-Cultural Factors Affecting Performance of Women Entrepreneurs in Bangladesh: An Exploratory Study on Cumilla City

2) UNDP (2004). Human Development Report, Oxford University Press.

3) Braun P (2011). Endeavour research fellowship, project report, Centre for regional innovation \& competiveness, University of Ballarat, Vic, Australia.

4) Begum, R. (1993) "Entrepreneurship in Small-scale Industry: A Case Study of engineering Units", Dhaka University Journal of Business Studies, Volume 14, pp.159-162.

5) Khanka, S. S. (2002) Entrepreneurial Development (New Delhi, India: S. Chand Group).

6) John, J. (2004), “Development of India: Gender Dimensions ", Labor and Development, Volume 10, Issue 1, pp. 113-125.

7) Rinkal, Divya, Sneha. (2004), "Women Entrepreneurs - Critical Issues." Proceedings of the 11th Summer Camp on "Entrepreneurial Stimulation for Children from May 2-7

8) Mitchell, B. C. (2004), "Motives of Entrepreneurs: A Case Study of South Africa", The Journal of Entrepreneurship, Volume13, Issue 2, pp. 167-183.

9) Watson, J. and S. Robinson (2003). "Adjusting for risk in comparing the performances of male- and female-controlled SMEs", Journal of Business Venturing, Volume 18, Issue 6, 773-788.

10) Garga, P \& Bagga, R (2009) "A comparative study of opportunities, growth and problems of women entrepreneurs" AsiaPacific Business Review, Jan-March, 2009.

11) Jesselyn, Mary (2004), "The Formal Institutional Framework of Entrepreneurship in the Philippines: Lessons for Developing Countries", The Journal of Entrepreneurship, Volume 13, Issue 2, pp. 185-203.

12) Gemechis, T. (2007). Attitude of college students towards entrepreneurship: A case study of Addis Ababa University and Rift Valley university college, (Addis Ababa, Ethiopia. Unpublished Thesis).

13) Jahed, A. M., Kulsum, U. and Akther, S. (2011). Women entrepreneurship in Bangladesh: A study on support services available for its development and growth. Global Management Review,) Volume 5, Issue 3, pp. 1-11.

14) Shane S. \& Venkataraman S. (2000) The promise of entrepreneurship as a field of research. Academy of Management Review, Volume 25,Issue 1,pp. 217-226

15) De Carolis D, Saparito P: (2006). Social capital, cognition, and entrepreneurial opportunities: a theoretical framework. Entrepreneurship Theory \& Practice, Volume 30, Issue 1,pp. 41-56.

16) Anderson, A. and Miller, C. (2002). Class matters: human and social capital in the entrepreneurial process. The Journal of Socio Economics, Volume, 32, Issue 1, pp. 17-36.

17) Roy, S., Tripathy, P., \& Tripathy, P. (2017). Assessment of Factors Affecting the Performance of Women Entrepreneurs in MSE in Polosara District of Ganjam, Odisha. British Journal of Economics, Management \& Trade, Volume 17, Issue 3, pp. 1-11.

18) Hasan FS, Almubarak (2016). MMS. Factors influencing women entrepreneurs' performance in SMEs. World Journal of Entrepreneurship, Management and Sustainable Development. Volume 12, Issue 2, pp. 82-101.

19) Samiti, V. (2006). A research study on Entrepreneurial Challenges for SC Persons in India. New Delhi : Planning Commission Government of India Yojana Bhawan.

20) Roomi MA, Parrott G (2008). Barriers to development and progression of women entrepreneurs in Pakistan. The Journal of Entrepreneurship. Volume 17, Issue 1, pp:59-72.

21) 21. Veciana, JM (1999): "Business Creation as a research program Scientific". European Management Journal and Business Economics, Volume 8, Issue 3, pp:11-36.

22) Arasti Z, Zandi F, Talebi K (2012) . Exploring the effect of individual factors on business failure in Iranian new established small businesses. International Business Research. Volume, 5, Issue 4, pp:2-6. 